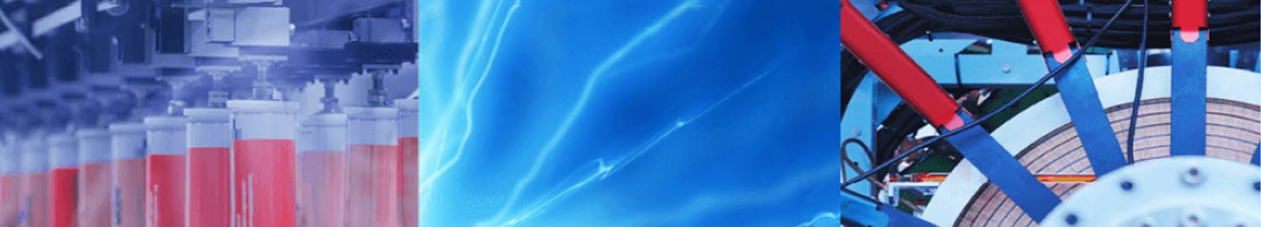

Research Article

\title{
Adding value to natural clays as low-cost adsorbents of methylene blue in polluted water through honeycomb monoliths manufacture
}

\author{
M. Ahrouch ${ }^{1,2} \cdot$ J. M. Gatica ${ }^{1} \mathbb{D} \cdot$ K. Draoui ${ }^{2} \cdot$ H. Vidal $^{1}$
}

Received: 17 July 2019 / Accepted: 5 November 2019 / Published online: 11 November 2019

(c) Springer Nature Switzerland AG 2019

\begin{abstract}
A natural Moroccan illite-smectite was used as an adsorbent for the removal of methylene blue (MB) from aqueous solutions. The clay was characterized by FTIR spectroscopy, TGA, SEM-EDS, X-ray fluorescence, XRD and $\mathrm{N}_{2}$ physisorption. The influence of $\mathrm{pH}$, temperature and time on the $\mathrm{MB}$ adsorption by the clay was investigated. The maximum equilibrium adsorption capacity was $100 \mathrm{mg} \mathrm{g}^{-1}$ at $45^{\circ} \mathrm{C}$. The kinetic behavior and the isotherms better-fitted with the pseudosecond-order and Langmuir models, respectively. Clay honeycomb monoliths ( 50 cells $\mathrm{cm}^{-2}$ ) were obtained by means of extrusion from the starting material without any additive except water. The structured filters exhibited better performance under dynamic conditions than the powdered clay, adding value to the application of this low-cost adsorbent.
\end{abstract}

Keywords Adsorption · Clay · Honeycomb monolith · Methylene blue

\section{Introduction}

The releases of textile industry are in general loaded with organic micropollutants, in particular different detergents and dyes. The latter are often used in excess and can be classified according to their structure as anionic and cationic [1, 2]. In aqueous solution, anionic dyes carry a net negative charge due to the presence of sulfonate $\left(\mathrm{SO}_{3}{ }^{-}\right)$groups $[3,4]$, while cationic dyes carry a net positive charge due to the presence of protonated amine or sulfurcontaining groups [5]. Due to their strong interaction with many surfaces of synthetic and natural fabrics [6], a broad variety of physicochemical and biological techniques has been developed and tested in the treatment of effluents loaded with these contaminants $[7,8]$. These processes include precipitation, ionic exchange, filtration on membrane and irradiation. However, these processes are often expensive and lead to the generation of large quantities of sludges, in addition to the formation of compounds derived from the degradation of the active molecules, which are sometimes even more toxic $[9,10]$. The accumulation and the low biodegradability of these compounds make the various treatments difficult to apply [11]. Among the wastewater treatment processes, adsorption remains a widely used approach for being easy to implement. The activated carbon is the adsorbent most largely employed, because of its great capacity of adsorption in agreement with its high specific surface area [12-14]. However, this adsorbent is expensive and poses the problem of its regeneration for a multiple use. The search for new effective and economic adsorbents thus proves attractive [15, 16]. In this context, the use of other adsorbent materials such as clays or natural zeolites is of great interest $[17,18]$.

The aim of our work was to optimize the adsorption performance of a natural argillaceous material, without any purification step, through its casting as structured filter for a possible replacement of the expensive adsorbents used in the polluted water treatment. In particular, we were interested in eliminating a cationic dye in aqueous solution by retention onto a local natural clay. Moreover, special attention was

$\triangle$ J. M. Gatica, josemanuel.gatica@uca.es | 'Departamento C.M., I.M. y Química Inorgánica, Universidad de Cádiz, 11510 Puerto Real, Spain. ${ }^{2}$ Laboratoire Matériaux et Systèmes Interfaciaux LMSI- Faculté des Sciences, Abdelmalek Essaâdi University, Tétouan, Morocco. 
paid to the fabrication of honeycomb monoliths from this material and their further use for the same application, taking into account that most previous studies reporting on the use of clays to retain dyes employed powders [19-22], references dealing with clay structured filters being still comparatively scarce [23]. Let us also consider the advantages of the honeycomb monolithic design for the treatment of a high volume/flow, which are characteristic of environmental applications, in comparison with packed-bed reactors in which pressure drop may become a serious problem [24].

Here, we specifically report on the ability of an interstratified illite-smectite to eliminate methylene blue (MB) present in water. This clay was selected because in a previous study [25] it demonstrated to have a high adsorption capacity even of heavy metals such as lead. On the other hand, MB was chosen considering the vast literature available regarding the use of this organic dye in adsorption studies in liquid phase [26-31] with which we could compare our own results. Moreover, it was also selected according to its significant presence in the wastewaters proceeding from the local Moroccan textile industry. Undoubtedly, there are other colorant molecules that from an environmental viewpoint could be also interesting to adsorb such as methyl orange, malachite green, crystal violet, Congo red, rhodamine $B$, among others. However, MB is the most studied one as well illustrated by the fact that there are even reviews just focused on this dye [30,31]. Since its discovery almost a century and half ago [27], $\mathrm{MB}$ is one of the most commonly used thiazine (cationic) dyes, and many different adsorbents have been reported for its removal from aqueous solutions [28]. Although it is not particularly hazardous, it has still some toxicity [29], and additionally, its quantitative detection is relatively simple. In this study, we first used a conventional batch-contact-time method [28], investigating the equilibrium of MB adsorption onto the powdered interstratified illite-smectite and fitting the data to the most used models (Langmuir, Freundlich) and also to the less employed Sips equation. The uptake of MB on the clay was examined as a function of adsorbate concentration, $\mathrm{pH}$, adsorption temperature and contact time. Furtherly, honeycomb monoliths were also manufactured from the starting clay powder and tested in the retention of methylene blue under dynamic conditions via recirculated plug-flow adsorption experiments. This study was performed in order to add value to these low-cost adsorbents and to investigate their potential for a real application.

\section{Materials and methods}

\subsection{Materials}

The clay used in this study as dye adsorbent was an interstratified illite-smectite collected from the north region of Morocco known as Chefchaouen. It had a CEC of $63 \mathrm{mEq} / 100 \mathrm{~g}$ as measured by the well-known cobalt (III)-hexamine trichloride method [32].

The basic dye used in this study was methylene blue (MB), from Fluka, with $\mathrm{C}_{16} \mathrm{H}_{18} \mathrm{C}_{1} \mathrm{~N}_{3} \mathrm{~S} \times 3 \mathrm{H}_{2} \mathrm{O}$ chemical formula which is of analytical grade. This cationic dye model presents decentralized positive charge on the organic framework, which could play a major role in keeping the species on the surface of the clay, the wavelength of $664 \mathrm{~nm}$ corresponding to its maximum absorbance [28]. Literature on the MB adsorption by clays is certainly vast, and it has even been used as a method to evaluate CEC and surface areas of clays [31-33]. In this research, working solutions of $\mathrm{MB}$ were prepared with deionized water and from a stock solution of $500 \mathrm{mg} \mathrm{L}^{-1}$ to give the required initial concentrations $\left(C_{0}=20-500 \mathrm{mg} \mathrm{L}^{-1}\right)$ for each experimental run [34].

\subsection{Clay monoliths preparation}

The clay honeycomb monoliths were obtained by extrusion of a paste, previously prepared by mixing the initial fine starting powder $(<10 \mu \mathrm{m})$ with the adequate amount of water ( $51 \mathrm{~mL} \mathrm{~g}^{-1}$ of paste). The extrudability of this paste, which did not require extra additives, was first predicted according to Casagrande's technique as it exhibited appropriate rheological parameters such as a liquid limit and a plasticity index of $50 \%$ and $29.6 \%$, respectively [35]. The resulting green monoliths were dried overnight at $60^{\circ} \mathrm{C}$ and subsequently calcined at $450^{\circ} \mathrm{C}$ for $4 \mathrm{~h}$. This treatment was chosen from thermogravimetric analysis results (see below) as the one allowing optimal enhancement of the mechanical resistance while preserving the clay structure, as learned from the previous experience with other clays [36]. The final monoliths presented a honeycomb-type circular section with a diameter of $1.4 \mathrm{~cm}$, a density of approx. 50 cells $\mathrm{cm}^{-2}, 0.33 \mathrm{~mm}$ of wall thickness and a $72 \%$ open frontal area (Fig. 1).

\subsection{Characterization of the adsorbents}

XRF compositional analysis of the starting clay was carried out in a Bruker S4 Pioneer spectrometer.

The textural characterization was performed by means of $\mathrm{N}_{2}$ physisorption at $-196{ }^{\circ} \mathrm{C}$ using an automatic Autosorb IQ (Quantachrome) analyzer. The clay samples (both in the form of powder and as honeycomb monoliths) were degassed at $150^{\circ} \mathrm{C}$ for $2 \mathrm{~h}$. The obtained isotherms were used to calculate their specific surface area $\left(S_{\mathrm{BET}}\right)$ and micro- and mesoporosity. Total pore volume $\left(V_{p}\right)$ data were calculated from the amount of nitrogen adsorbed at a 0.97 
Fig. 1 A Image of the starting clay powder (a) and clay honeycomb monoliths prepared from it after simple extrusion plus drying (b), additional calcination at $450^{\circ} \mathrm{C}$ for $4 \mathrm{~h}$ (c) and further use to adsorb methylene blue (d); B geometric characteristics of the clay honeycomb monoliths; and $\mathbf{C}$ schematic diagram of the experimental setup for the dynamic adsorption studies, in which a centrifugal pump was employed

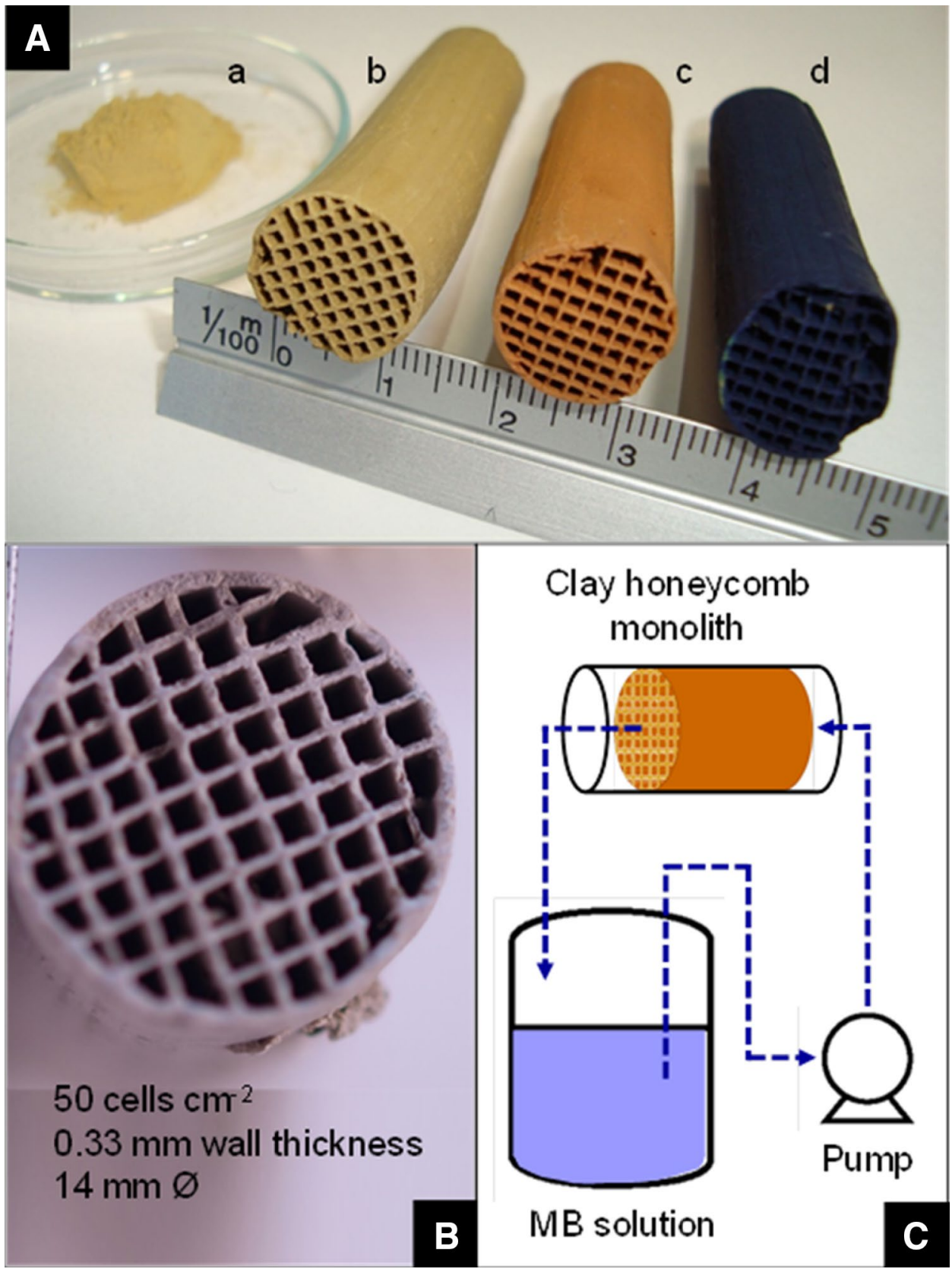

relative pressure value $\left(P / P_{0}\right)$. Pore size distribution and the average pore were examined by the $\mathrm{BJH}$ method from the desorption branch of the isotherms.

The FTIR spectra in transmission mode were obtained using a Thermo vertex 70 FTIR spectrophotometer. About $1 \mathrm{mg}$ of sample clay was mixed with approximately $200 \mathrm{mg}$ of dried $\mathrm{KBr}$ to get pellets. Measurements were taken over the range $4000-400 \mathrm{~cm}^{-1}$ in the absorbance mode, with a spectral resolution of $4 \mathrm{~cm}^{-1}$. This technique was employed to study the clay samples both before and after the MB adsorption.
The thermogravimetric analysis (TGA) was carried out under air in a Shimadzu TGA-50 thermobalance over $50 \mathrm{mg}$ of powdered samples using a heating rate of $10^{\circ} \mathrm{C} \mathrm{min}^{-1}$.

SEM images and EDS compositional data of the clay powder were obtained using a QUANTA-200 scanning electron microscope equipped with a Phoenix microanalysis system using a nominal resolution of $3 \mathrm{~nm}$. SEM images of the clay calcined at $450^{\circ} \mathrm{C}$ for $4 \mathrm{~h}$ and of the clay monolith after the same treatment were acquired in a field emission gun (FEG) scanning electron microscope (Nova NanoSEM 450).

XRD studies were carried out in a Bruker diffractometer, D8 Advance 500 model. Diffractograms were recorded using CuKa radiation, and the $2 \theta$ angle ranged from $1.5^{\circ}$ to 
$75^{\circ}$, with a step of $0.017^{\circ}$ and a counting time per step of $1 \mathrm{~s}$. Refinement of the analysis was performed by applying a Rietveld method by means of the FullProf program [37]. In addition, semiquantitative analysis of the mineralogical composition was made by means of the PowderCell 2.4 software.

\subsection{Batch adsorption experiments}

The adsorption of MB over the fresh clay powder was studied in a batch equilibration system. Different parameters including initial concentration of $\mathrm{MB}$, contact time, stirring speed and $\mathrm{pH}$ of the $\mathrm{MB}$ solutions were adjusted, the latter by adding $0.1 \mathrm{~N} \mathrm{HNO}_{3}$ or $0.1 \mathrm{~N} \mathrm{NaOH}$ solutions. In general, the adsorption experiments were carried out by varying the initial concentrations from 50 to $500 \mathrm{mg} \mathrm{L}^{-1}$. In each case, $0.2 \mathrm{~g}$ of sample was added to a conical flask which contained the $\mathrm{MB}$ solution $(50 \mathrm{~mL}$ ). Two types of experiments were performed. First, the adsorption kinetic curves for two initial concentrations of $\mathrm{MB}\left(200\right.$ and $\left.300 \mathrm{mg} \mathrm{L}^{-1}\right)$ were obtained at room temperature in order to study the effect of contact time (1 min-4 h) on the adsorption of MB on the clay. The suspensions were continuously shaken at $150 \mathrm{rpm}$, and the experimental data were examined by pseudo-first-order and pseudo-second-order kinetics [38, 39]. For the fitting, only data up to saturation (approx. $30 \mathrm{~min}$ ) were considered. In the second type of experiments, the suspensions were stirred at the same speed as before during $4 \mathrm{~h}$ (considering the results from the kinetic study) under variable temperature conditions $\left(20,25,35\right.$ and $\left.45^{\circ} \mathrm{C}\right)$. The adsorption experiments were carried out in a closed system. The MB solutions were kept in thermal equilibrium using an automatic thermostat system, including a water bath and an integral shaker drive. Three theoretical isotherm models, Langmuir, Freundlich and Sips [25], were considered to fit the experimental data.

In all cases, the remaining $M B$ in balance was analyzed by UV-visible spectrophotometry. The amounts of MB adsorbed were calculated from the difference between initial and final or equilibrium concentration of the corresponding solutions.

\subsection{Dynamic adsorption experiments}

The capacity to adsorb MB by the clay honeycomb monoliths was studied at room temperature in a homemade system (Fig. 1), using approx. $6.5 \mathrm{~g}$ weighted monoliths
( $L=5.2 \mathrm{~cm}$ approx.) and a $1200 \mathrm{~cm}^{3} \mathrm{~min}^{-1}$ recirculated flow of the MB aqueous solution ( $1 \mathrm{~L}$ ). This study allows testing the potential application of the monoliths in the treatment of polluted liquid effluents under more realistic conditions. Experimental conditions (mass of adsorbent and dye concentration) were different to those selected for the batch experiments because the two types of experiments are not comparable. In order to make a comparison with the powder, a packed column containing the same quantity of powdered clay $(\varnothing=1.5 \mathrm{~cm}, L=2.5 \mathrm{~cm})$, with quartz wool at the outlet to avoid powder drag, and previously submitted to the same calcination treatment as the monolith $\left(450^{\circ} \mathrm{C}\right.$, $4 \mathrm{~h}$ ), was also tested in the same experimental setup of the monolith. Blank experiments confirmed previously a negligible MB adsorption over the quartz wool. In both cases, column and monolith, two different initial concentrations of MB, were studied: 20 and $100 \mathrm{mg} \mathrm{L}^{-1}$. As for the batch experiments, the adsorption capacity was analyzed by measuring the absorbance at $664 \mathrm{~nm}$ of the residual liquid phase, after filtration, in a UV-visible Cary 50 spectrophotometer from Varian.

\section{Results and discussion}

\subsection{Sample characterization}

The chemical composition of the employed natural clay as estimated by XRF analysis is given in Table 1. It is remarkable that it resembles that typically exhibited by other smectiteand illite-type minerals with predominant presence of silicon, aluminum and iron oxides $[40,41]$.

The clay FTIR spectrum is presented in Fig. 2. The sharp band at $3625 \mathrm{~cm}^{-1}$, the broad shoulder at $3420 \mathrm{~cm}^{-1}$ and the small peak at $1630 \mathrm{~cm}^{-1}$ are attributable to the framework $\mathrm{OH}$ groups stretching, interlayer water $\mathrm{OH}$ stretching and $\mathrm{H}_{2} \mathrm{O}$ deformation band typically observed in many smectites [42]. Silanol groups $(\mathrm{Si}-\mathrm{OH})$ are therefore spread over the clay surface. This is a very active surface group, which could interact with polar organic compounds as methylene blue during the adsorption process [43]. On the other hand, the most intense bands are perfectly understandable in terms of clay lattice vibrations, some of which are of the same nature as those of quartz (Si-O-Si or O-Si-O vibrations) [44], except the small peak at $1384 \mathrm{~cm}^{-1}$ which might correspond to some carbonates [45]. Their presence in any case must not be significant considering the relative low intensity of the mentioned peak [40, 41]. Figure 2 also shows that calcination

Table 1 X-ray fluorescence analysis of oxide content (wt\%) for the clay sample investigated

\begin{tabular}{lllllllllllll}
\hline $\mathrm{SiO}_{2}$ & $\mathrm{Al}_{2} \mathrm{O}_{3}$ & $\mathrm{Fe}_{2} \mathrm{O}_{3}$ & $\mathrm{Cr}_{2} \mathrm{O}_{3}$ & $\mathrm{MgO}$ & $\mathrm{CaO}$ & $\mathrm{K}_{2} \mathrm{O}$ & $\mathrm{TiO}_{2}$ & $\mathrm{~V}_{2} \mathrm{O}_{5}$ & $\mathrm{SO}_{3}$ & $\mathrm{ZnO}$ & $\mathrm{SrO}$ \\
\hline 60.4 & 21.5 & 6.8 & $<0.1$ & 1.2 & 2.2 & 2.0 & 1.1 & $<0.1$ & 0.1 & $<0.1$ & $<0.1$ \\
\hline
\end{tabular}




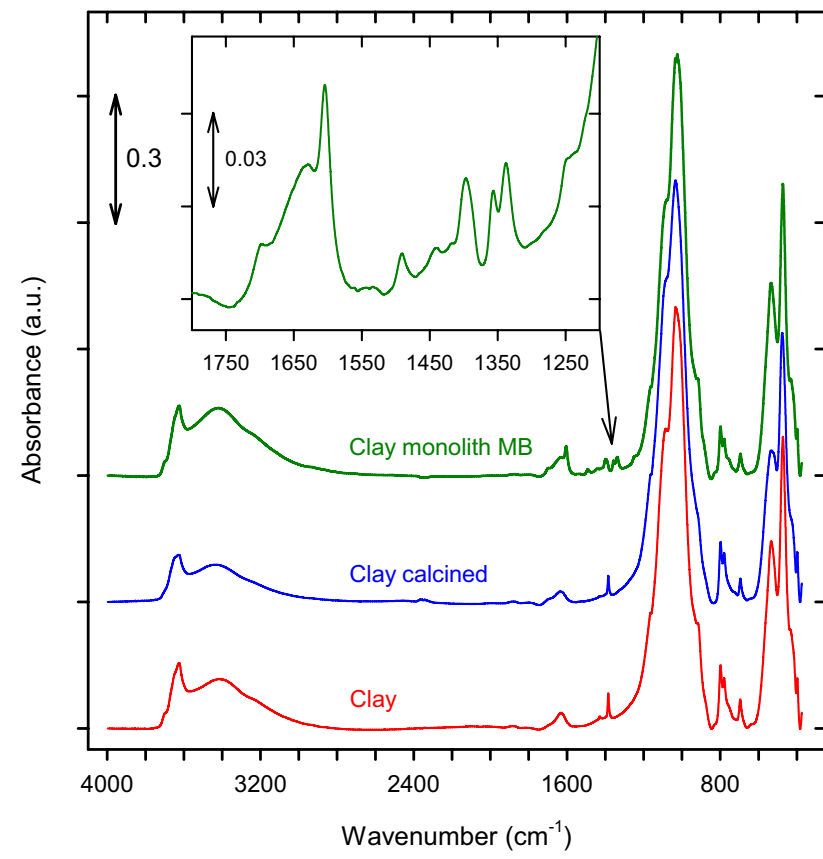

Fig. 2 FTIR spectra corresponding to the powdered clay sample, both fresh and calcined at $450^{\circ} \mathrm{C}$ for $4 \mathrm{~h}$, and crushed pieces of the clay honeycomb monolith after MB adsorption. Details of the MB adsorption IR bands are shown in the inset

of the clay at $450^{\circ} \mathrm{C}$ for $4 \mathrm{~h}$, the thermal treatment applied to the clay honeycomb monoliths as the last step of their preparation to make them waterproof, hardly modifies the infrared spectrum. Only a slight decrease in the bands above $3000 \mathrm{~cm}^{-1}$ is observed, what can be denotative of some dehydroxylation and dehydration of the clay [42].

The thermal stability of the fresh clay, the clay calcined at $450^{\circ} \mathrm{C}$ for $4 \mathrm{~h}$ and the clay-based monolith submitted to the same treatment was also studied. As shown in Fig. 3, the thermal analysis reveals the existence of two main different stages of weight loss for the fresh clay. The first loss occurs practically from room temperature up to approximately $200{ }^{\circ} \mathrm{C}$ and might reasonably correspond to the release of adsorbed water. The second weight loss, which extends up to around $600^{\circ} \mathrm{C}$, should be basically related to dehydroxylation of the different silicate phases present in the clay, not discarding some contribution of interlayer water. In the case of the calcined sample, there is a reasonable decrease in the weight loss with almost complete disappearance of the first stage. Finally, the slightly higher mass loss in the clay honeycomb monolith if compared to the latter is attributable to a higher humidity degree reached from exposure to the air after the calcination treatment. In any case, the similarity of its profile respect to the calcined powder suggests that the extrusion process has no effect on the composition or structure of the clay. Moreover, the thermogravimetric analysis also points

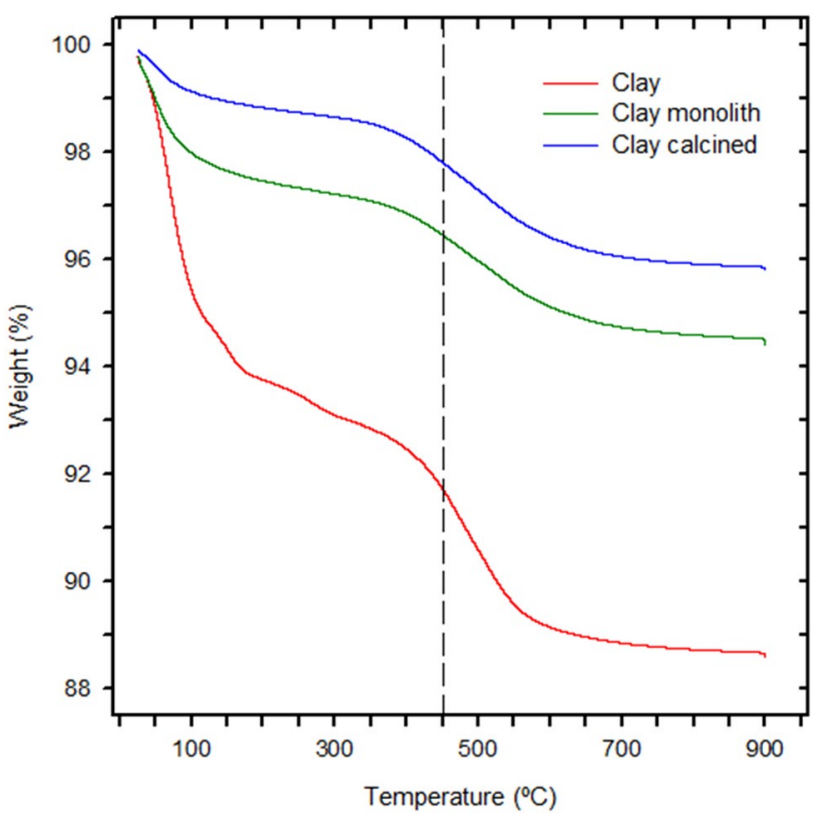

Fig. 3 TGA profiles of the clay sample as-received, after calcination at $450{ }^{\circ} \mathrm{C}$ for $4 \mathrm{~h}$, and after extrusion as a honeycomb monolith plus calcination at $450^{\circ} \mathrm{C}$ for $4 \mathrm{~h}$. The dashed line indicates the temperature at which a waterproof monolith can be obtained

to the suitability of the calcination treatment at $450^{\circ} \mathrm{C}$ for leading to a monolith that is resistant to the aqueous phase while mostly preserving the initial clay.

The XRD study gave results in agreement with the above. As can be observed in Fig. 4, the diffractogram of the raw clay can be interpreted as the sum of contributions of different phases. In particular, the relatively most intense peaks can be assigned to quartz (most likely present as large crystals), in good agreement with the FTIR analysis, while the rest is mainly associated with an interstratified silicate composed of illite-muscovite and smectite-montmorillonite and with topaz. The presence of all these hydroxylated silicate minerals is also consistent with the TGA study above commented. Moreover, the Rietveld analysis indicated that the best-fitting of the experimental data is obtained when other minority phases are considered such as lazurite, zircon, rutile, albite, boehmite, anatase, gibbsite, augelite, glauberite and glauconite. The presence of these phases, although much less significant, might justify the content of elements such as $\mathrm{Al}, \mathrm{Fe}, \mathrm{Mg}$, $\mathrm{Ca}, \mathrm{K}$, Ti or $\mathrm{S}$ measured by XRF (Table 1). In addition, the semiquantitative analysis allowed estimating the mineralogical composition of our clay as follows: $43.0 \%$ smectite, $23.8 \%$ illite, $30.2 \%$ quartz and $2.9 \%$ topaz. This confirms that the contribution of impurities, on the other hand, is reasonable for a natural clay that has not been treated/ purified with the intention to simplify the overall manufacture of our low-cost adsorbent filters. It is also remarkable 


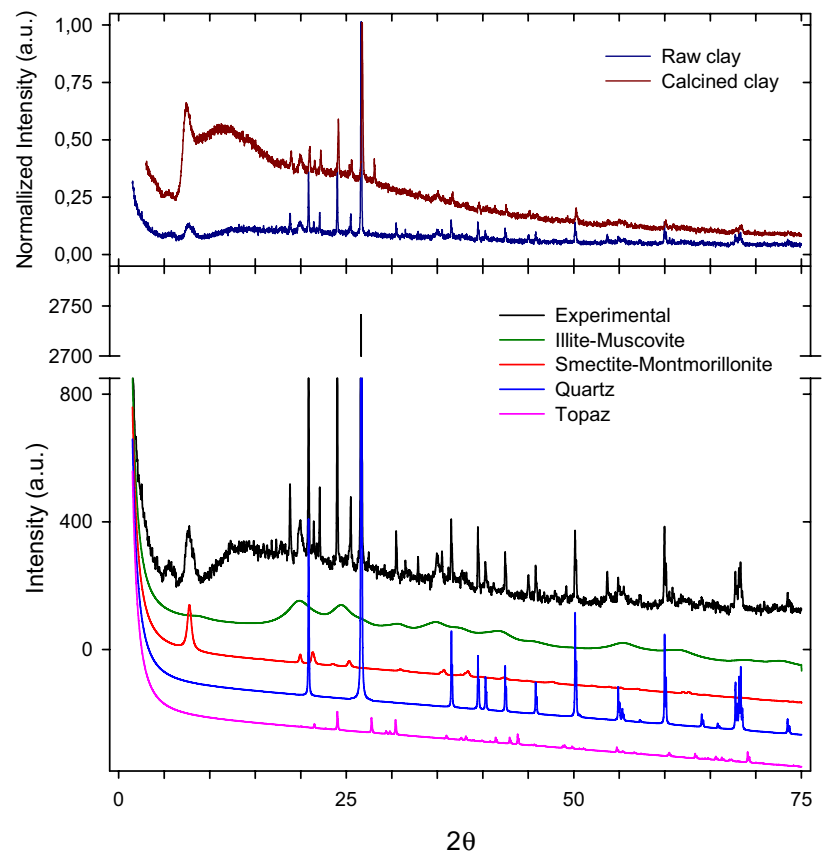

Fig. 4 Normalized X-ray diffractograms obtained for the clay asreceived and after calcination at $450{ }^{\circ} \mathrm{C}$ for $4 \mathrm{~h}$ (upper part), and experimental X-ray diffractogram of the raw clay along with its main phases detected according to Rietveld analysis, their Y-axis position being displaced for the sake of clarity (lower part). Structural data for the Rietveld analysis were obtained from the Inorganic Crystal Structure Database (ICSD) and Crystallographic Open Database (OCD) as follows: illite-muscovite, ICSD 63123; smectitemontmorillonite, COD 9002779; Quartz, ICSD 63532; Topaz, ICSD 72938 that the analysis of the diffractogram obtained for the calcined clay (upper part of Fig. 4) was similar to that of the fresh clay, so confirming that the calcination treatment did not significantly alter the structure of the clay.

The $\mathrm{N}_{2}$ adsorption-desorption isotherms and $\mathrm{BJH}$ pore size distribution curves of both clay powder and clay honeycomb monoliths are plotted in Fig. 5. Curves corresponding to the clay powder calcined at the same temperature as the monolith are also included as a reference. All the isotherms showed the typical II-type sorption behavior, characteristic of mainly macroporous adsorbents according to the IUPAC classification, with H3-type hysteresis loop denotative of plate-like particles giving rise to slit-shaped pores [46]. On the other hand, the BET surface area and pore volumes were calculated from the adsorption data, the values being summarized in Table 2. As expected, the calcination treatment induces some decrease in porosity and consequently of specific surface area. On the contrary, extrusion of the clay has almost no effect on the textural properties, since the values obtained for the calcined powder and honeycomb monolith are very similar. It should be also noticed that all the samples, although mainly macroporous, have some meso- and microporosity, put into evidence by the pore size distribution curves of Fig. 5.

Finally, Fig. 6 shows a representative SEM image (a) and its corresponding EDS spectrum (b) obtained for the fresh clay sample. As can be noticed, the clay is composed of an agglomerate of particles of heterogeneous size and irregular shape. It is also displayed inter-particle/agglomerate void spaces that may contribute to porosity as stated above. The look resembles very much that observed previously for other natural clays of smectite type $[36,40,41]$.
Fig. $5 \quad \mathrm{~N}_{2}$ adsorption-desorption isotherms and pore size distribution curves of the clay sample as-received, after calcination at $450^{\circ} \mathrm{C}$ for $4 \mathrm{~h}$, and after extrusion as a honeycomb monolith plus calcination at $450^{\circ} \mathrm{C}$ for $4 \mathrm{~h}$
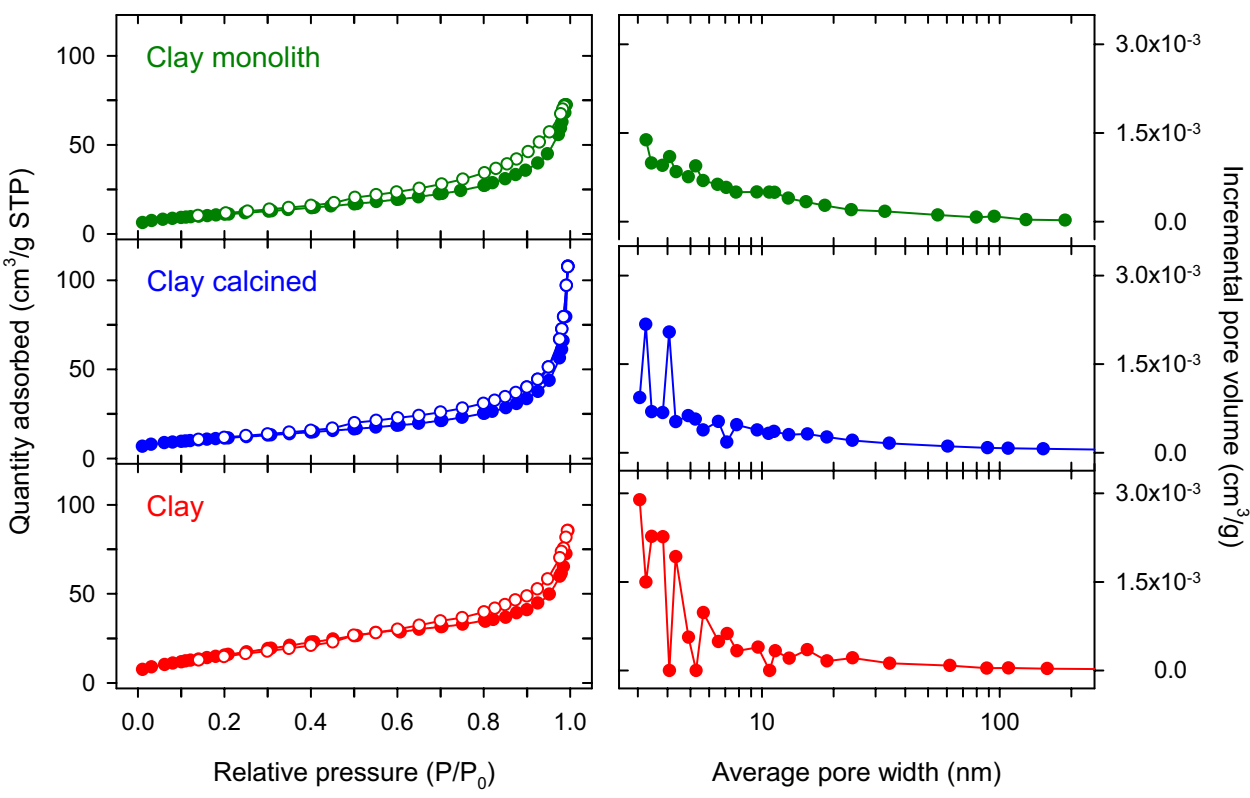
Table 2 Textural data of the investigated samples as estimated from $\mathrm{N}_{2}$ physisorption

\begin{tabular}{llll}
\hline Sample & $\begin{array}{l}\mathrm{S}_{\mathrm{BET}} \\
\left(\mathrm{m}^{2} \mathrm{~g}^{-1}\right)\end{array}$ & $\begin{array}{l}\text { Total pore } \\
\text { volume } \\
\left(\mathrm{cm}^{3} \mathrm{~g}^{-1}\right)\end{array}$ & $\begin{array}{l}\text { Micropore } \\
\text { volume } \\
\left(\mathrm{cm}^{3} \mathrm{~g}^{-1}\right)\end{array}$ \\
\hline Fresh clay & 61 & 0.093 & 0.021 \\
Calcined clay $^{\mathrm{a}}$ & 41 & 0.087 & 0.018 \\
Clay-based monolith $^{\mathrm{a}}$ & 40 & 0.086 & 0.019 \\
\hline
\end{tabular}

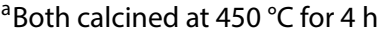

In the same way, similar images were obtained for the calcined powder (Fig. 6c), demonstrating that no significant morphological changes occur as a result of the calcination treatment. Regarding the clay monolith, the apparent loss of surface roughness in the images obtained for this sample (Fig. 6d) can be reasonably attributed to the higher compaction of the clay grains as a result of the extrusion step. Also noticeable, except gold that is present due to its use for metalizing the raw clay sample, all the elements detected by EDS analysis are consistent with both the XRF analysis and XRD study above discussed.

\subsection{Adsorptive performance of the powdered clay}

\subsubsection{Effect of $\mathrm{pH}$}

The effect on the MB adsorption by the studied clay at varying the solution $\mathrm{pH}$ is shown in Fig. 7a. The results indicate that the dye removal efficiency slightly increases between $\mathrm{pH}$ values of 2 and 8 . A similar trend was observed by other authors studying the adsorption of $\mathrm{MB}$ on different natural clays of smectite $[28,47]$ or diatomite [43] type, but it contrasts with results obtained for kaolin [18]. It is also noteworthy that the adsorption capacity of our adsorbent increased remarkably above $\mathrm{pH}$ 8, especially with increasing the $\mathrm{pH}$ value from 10 up to 12 . In
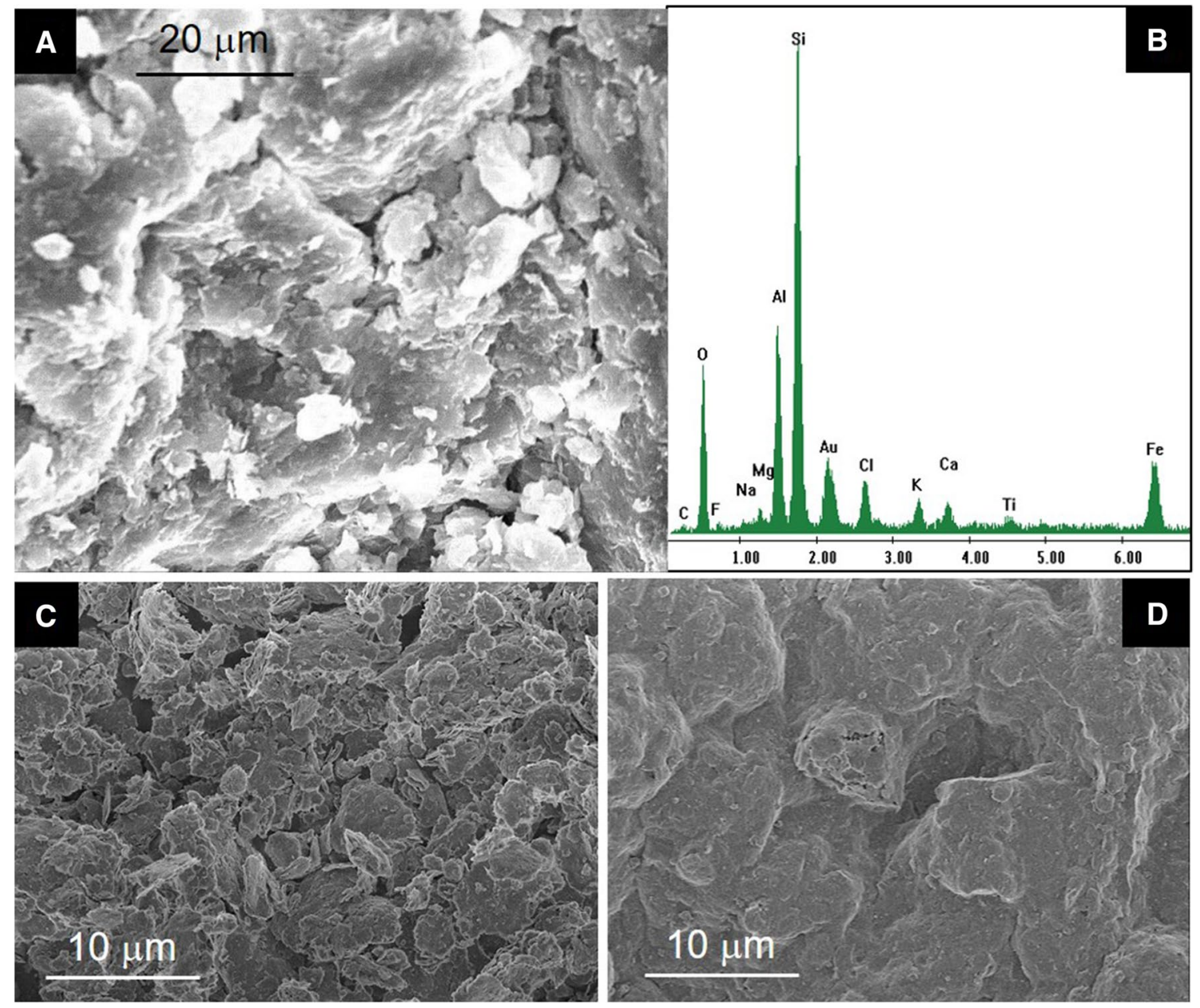

Fig. 6 SEM image (a) and EDS spectrum (b) of the fresh clay powdered sample, and SEM images of the clay calcined at $450{ }^{\circ} \mathrm{C}$ for $4 \mathrm{~h}(\mathbf{c})$ and the clay honeycomb monolith calcined at the same conditions (d) 

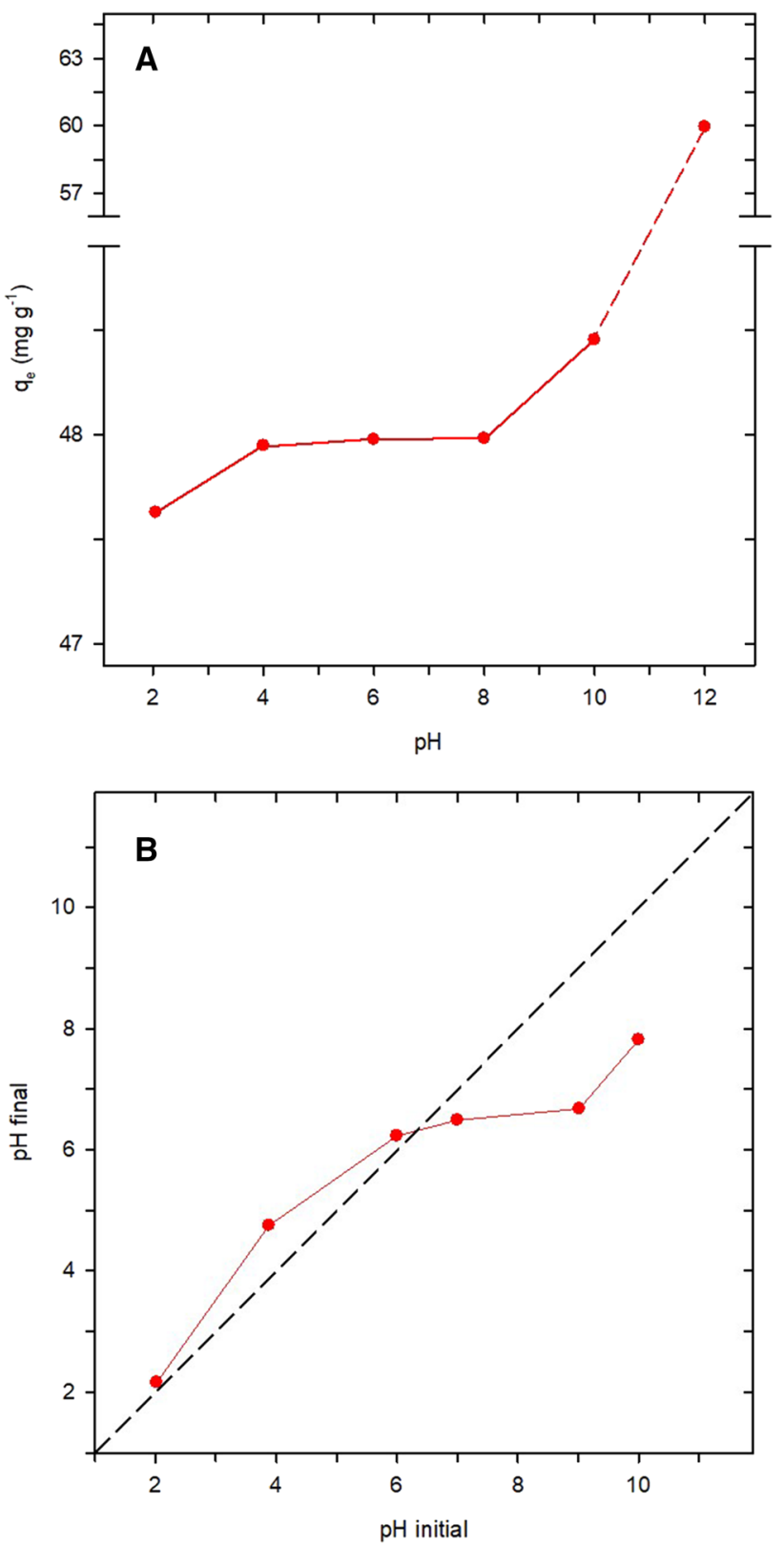

Fig. 7 a Effect of $\mathrm{pH}$ on the adsorption of MB (initial concentration $=240 \mathrm{mg} \mathrm{L}^{-1}$, stirring speed $=150 \mathrm{rpm}$, temperature $=25^{\circ} \mathrm{C}$, contact time $=240 \mathrm{~min}$ and adsorbent dosage $=0.1 \mathrm{~g} / 25 \mathrm{~mL}$ ); $\mathbf{b}$ determination of the point of zero charge (pzc) value for the clay sample. The intersection of solid and dashed lines indicates the $\mathrm{pH}$ values at which the $\mathrm{pH}$ of the dye solution before $\left(\mathrm{pH}_{\mathrm{i}}\right)$ and after $\left(\mathrm{pH}_{\mathrm{f}}\right)$ the contact with the clay is the same

order to understand this dependence of the MB adsorption with the $\mathrm{pH}$, we performed additional measurements to estimate the point of zero charge (pzc) of the studied clay sample which resulted to be 6.4 , observing that the surface of the adsorbent becomes negatively charged, especially above pH 8 (Fig. 7b). This effect can explain why

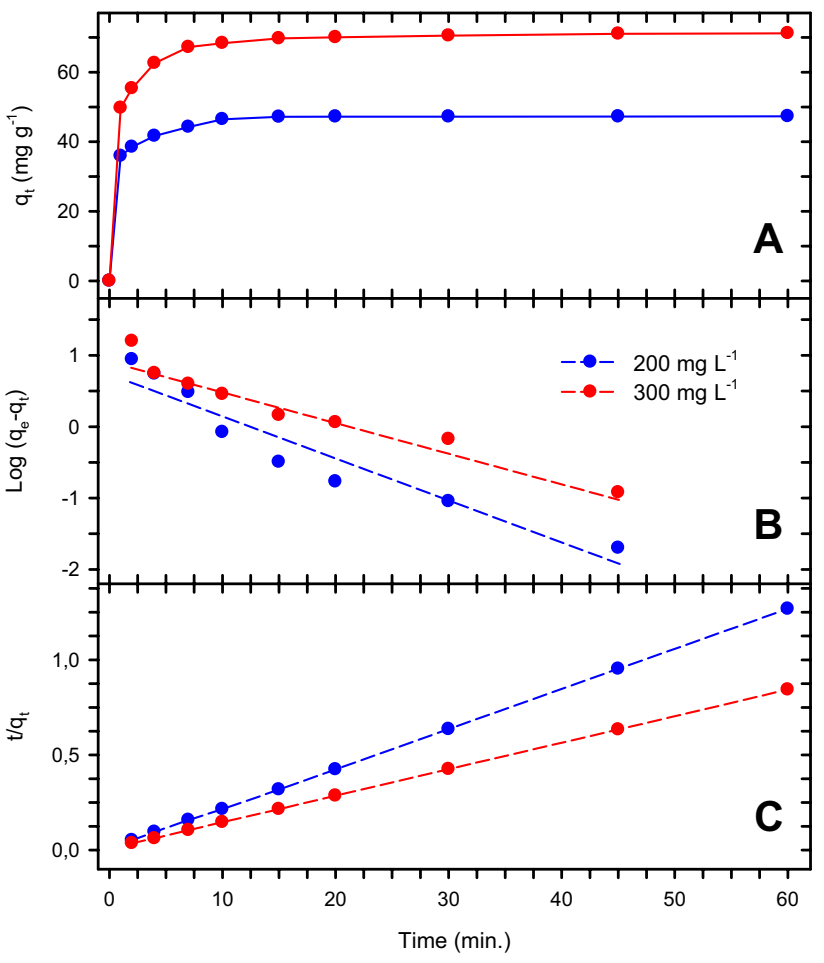

Fig. 8 Adsorption kinetics curves for the adsorption of $M B$ on the clay sample at room temperature (a). The maximum percentage of $\mathrm{MB}$ removal corresponding to the initial concentrations of $200 \mathrm{mg} \mathrm{L}^{-1}$ and $300 \mathrm{mg} \mathrm{L}^{-1}$ was $25 \%$ in both cases. The figure also includes kinetic modeling to a pseudo-first-order (b) and to a pseudo-second-order (c)

above this value the electrostatic interaction with the MB cationic molecule is particularly favored [13].

\subsubsection{Adsorption kinetics}

Figure 8a shows the MB adsorption capacity of our clay at room temperature as a function of time under the dye initial concentrations of $200 \mathrm{mg} \mathrm{L}^{-1}$ and $300 \mathrm{mg} \mathrm{L}^{-1}$. Notice that the adsorption process was rapid in the first minute, then continued with a slower rate during the following $10 \mathrm{~min}$, and finally reached a nearly constant value after 30 min.

As previously mentioned in the experimental section, the results were analyzed by using the models of pseudofirst-order and pseudo-second-order $[48,49]$. The rate constants of the MB adsorption on the clay were determined graphically (Fig. 8b, c), leading to the results summarized in Table 3. The highest correlation coefficient, that denotes the best-fitting of the experimental data, was found for a pseudo-second-order model. This result agrees with many previous studies that employed not only natural clays $[18,21,28,47,50]$ but also other proposed synthetic materials such as activated carbons from biomass $[13,16]$, 
Table 3 Kinetic parameters for the adsorption of MB on the clay sample

\begin{tabular}{|c|c|c|c|c|c|c|c|}
\hline \multirow{2}{*}{$\begin{array}{l}C_{0} \\
\left(\mathrm{mg} \mathrm{L}^{-1}\right)\end{array}$} & \multirow{2}{*}{$\begin{array}{l}q_{\mathrm{e}} \exp \\
\left(\mathrm{mg} \mathrm{g}^{-1}\right)\end{array}$} & \multicolumn{3}{|c|}{ Pseudo-first-order } & \multicolumn{3}{|c|}{ Pseudo-second-order } \\
\hline & & $\begin{array}{l}k_{1} \\
\left(\min ^{-1}\right)\end{array}$ & $\begin{array}{l}q_{\mathrm{e}} \mathrm{cal} \\
\left(\mathrm{mg} \mathrm{g}^{-1}\right)\end{array}$ & $R^{2}$ & $\begin{array}{l}k_{2} \\
\left(\mathrm{~g} \mathrm{mg}^{-1} \mathrm{~min}^{-1}\right)\end{array}$ & $\begin{array}{l}q_{\mathrm{e}} \mathrm{cal} \\
\left(\mathrm{mg} \mathrm{g}^{-1}\right)\end{array}$ & $R^{2}$ \\
\hline 200 & 47.3 & 0.139 & 5.8 & 0.902 & 0.054 & 47.6 & 0.999 \\
\hline 300 & 71.2 & 0.097 & 9.4 & 0.934 & 0.029 & 71.4 & 0.999 \\
\hline
\end{tabular}

oxides [15] and silicates [19]. In addition, Table 4 shows the pseudo-second-order model constant rate values reported for different adsorbents allowing a comparison with our own results.

\subsubsection{Adsorption isotherms}

The adsorption isotherms were obtained by monitoring the evolution of the retention capacity at equilibrium, $q_{\mathrm{e}}$ $\left(\mathrm{mg} \mathrm{g}^{-1}\right)$, for each initial concentration of the pollutant as function of the equilibrium concentrations $\left(\mathrm{mg} \mathrm{L}^{-1}\right)$ at different temperatures $\left(20,25,35\right.$ and $\left.45^{\circ} \mathrm{C}\right)$. The obtained results are plotted in Fig. 9a.

The experiments carried out show that the capacity of adsorption increases with the initial concentration. In addition, the shape of the obtained isotherms suggests the saturation of the surface sites and therefore the formation of the monolayer. A similar trend was found by other authors when studying MB adsorption on different natural clays $[18,43,47]$. Moreover, according to Giles classification [51], our isotherms, with independence of the temperature studied $\left(20-45^{\circ} \mathrm{C}\right)$, are of type $\mathrm{H}$ which are the result of the dominance of strong ionic adsorbate-adsorbent interactions [52]. In this sense, a chemical adsorption of positively charged functional groups of $M B$ on the negatively charged surface groups of the clay is proposed.
Fitting of adsorption isotherms of MB on the clay sample by the Langmuir model was also studied by plotting $C_{e} / q_{\mathrm{e}}$ versus $C_{e}$. According to Fig. $9 \mathrm{~b}$, the values obtained in such representation follow an almost perfect linear trend what indicates that the Langmuir model is adequate for a good description of our adsorption isotherms. From the above data, monolayer adsorption capacities were estimated in each case, resulting to be $100,95,94$ and $92 \mathrm{mg} \mathrm{g}^{-1}$ at $45,35,25$ and $20^{\circ} \mathrm{C}$, respectively. The relatively small dispersion of these values in the studied range suggests that the temperature has not a great effect on the adsorption capacity. It is remarkable that the maximum adsorption capacity measured in this study $\left(100 \mathrm{mg} \mathrm{g}^{-1}\right)$ is an intermediate value in the context of adsorption capacities for natural materials [31]. Moreover, our result is higher than that reported for other natural clays [21], low-cost recycled wasted materials from tea or rice [15], or even similar to that of more sophisticated adsorbents with clearly higher specific surface area, either activated carbon-based [15] or mesoporous silicates [19]. Additionally, Table 5 summarizes the maximum adsorption capacity values reported for other adsorbents in the literature. Comparing them with the results obtained in this work, our Moroccan illite-smectite can be employed as low-cost adsorbent and considered as an alternative to other materials such as activated carbon and mesoporous silicate for the MB removal.
Table 4 Parameters determined by theoretical models for the adsorption of MB over different adsorbents

\begin{tabular}{lllll}
\hline Adsorbent & $\begin{array}{l}K_{2} \\
\left(\mathrm{~g} \mathrm{mg}^{-1} \mathrm{~min}^{-1}\right)^{\mathrm{a}}\end{array}$ & $\begin{array}{l}K_{\mathrm{L}} \\
\left(\mathrm{L} \mathrm{mg}^{-1}\right)^{\mathrm{b}}\end{array}$ & $\begin{array}{l}\Delta \mathrm{G}^{\circ} \\
\left(\mathrm{KJ} \mathrm{mol}^{-1}\right)\end{array}$ & References \\
\hline Activated carbon & - & $0.04 / 0.07$ & - & {$[13]$} \\
Mesoporous birnessite & - & $0.27 / 0.44$ & $-4.3 /-8.8$ & {$[15]$} \\
Activated carbon & 0.057 & 0.03 & $-7.9 /-12.4$ & {$[16]$} \\
Kaolin and zeolite & $0.014 / 0.63$ & - & $81.5 / 88.5$ & {$[18]$} \\
Mesoporous silicate material (dolomite) & $0.0001 / 0.0007$ & $0.12 / 0.18$ & $-0.3 /-4.5$ & {$[19]$} \\
Natural serpentine & 0.001 & 0.05 & $-0.3 /-3.0$ & {$[21]$} \\
Montmorillonite & $0.004 / 0.042$ & $0.01 / 0.77$ & - & {$[28]$} \\
Moroccan clays & $0.003 / 0.13$ & $0.27 / 2.12$ & $-7.0 / 1.4$ & {$[46]$} \\
Moroccan diatomite & 0.015 & 1.30 & $-30.8 /-35.3$ & {$[47]$} \\
Natural clay mineral & - & $-0.07 /-0.03$ & $6.8 / 7.4$ & {$[51]$} \\
Natural Moroccan illite-smectite & $0.029 / 0.054$ & $1.11 / 1.91$ & $-32.7 /-33.7$ & This work \\
\hline
\end{tabular}

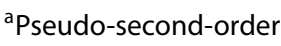

${ }^{\mathrm{b}}$ Langmuir model 

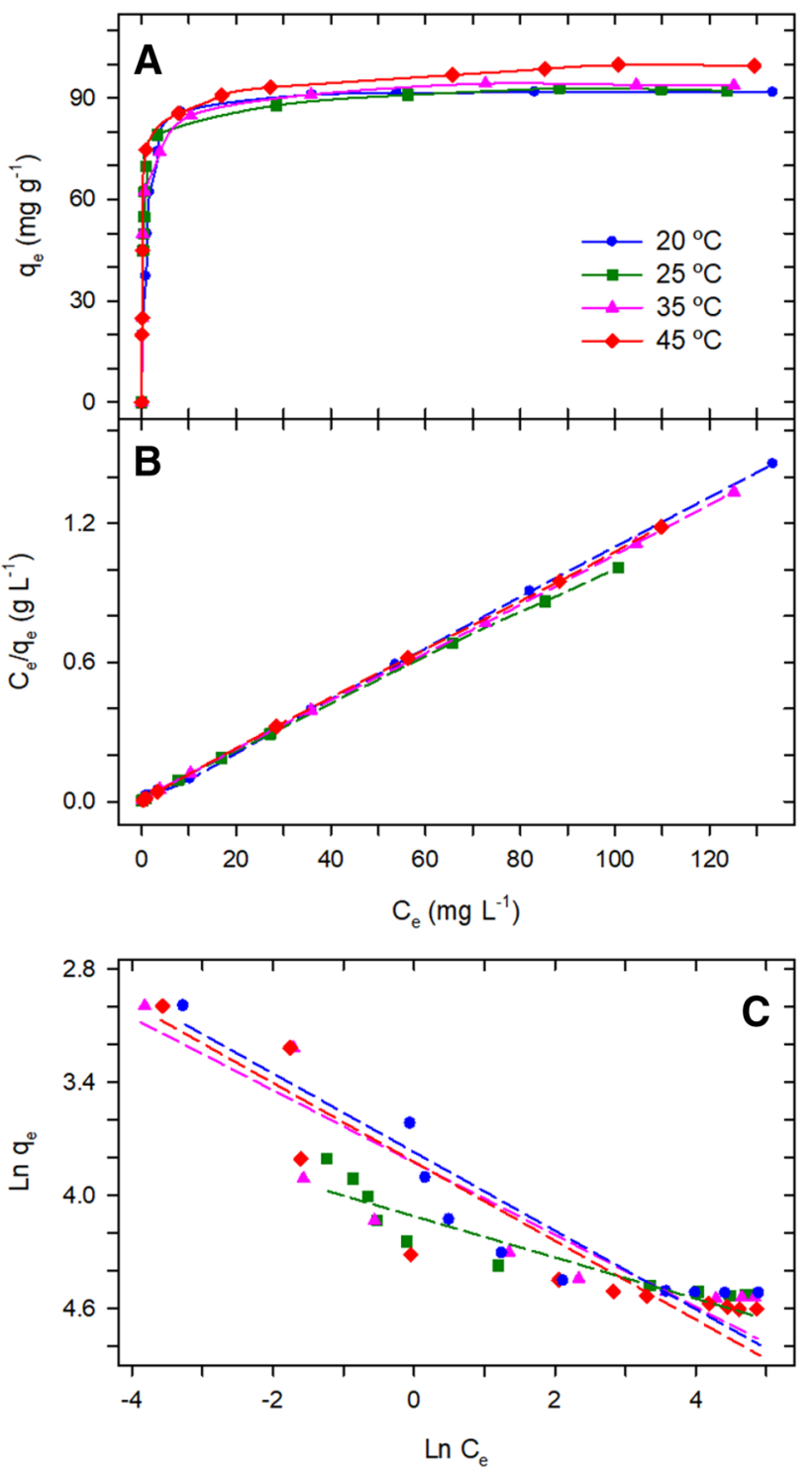

Fig. 9 Adsorption isotherms and effect of the temperature of the MB solution in contact with the clay sample (a); fitting of the isotherms data to a Langmuir model (b); and fitting of the isotherms data to a Freundlich model (c)

The results of fitting the adsorption isotherms to the Freundlich model are represented in Fig. 9c. On the other hand, the parameters values of Langmuir, Freundlich and Sips models are summarized in Table 6. Their comparison allows concluding that the experimental data fit better with the Langmuir model, according to the respective correlation coefficients $\left(R^{2}\right)$. Such conclusion agrees with that of other authors who also found that data corresponding to $\mathrm{MB}$ adsorption onto different natural clays were better described by the Langmuir isotherm model [21, 28, 43, 47], being their corresponding constant values in a reasonably similar range (Table 4). Additionally, the results found in this work suggest that MB adsorption occurs like a monolayer on
Table 5 Maximum adsorption capacity of various adsorbents for MB according to Langmuir model

\begin{tabular}{lll}
\hline Adsorbent & $\begin{array}{l}q_{\max } \\
(\mathrm{mg} / \mathrm{g})\end{array}$ & References \\
\hline Mesoporous birnessite & 113 & {$[15]$} \\
Kaolin and zeolite & $45-22$ & {$[18]$} \\
Mesoporous silicate material (dolomite) & 92 & {$[19]$} \\
Natural serpentine & 58 & {$[21]$} \\
Raw kaolin & 14 & {$[33]$} \\
Moroccan raw and decanted clays & $49-114$ & {$[46]$} \\
Moroccan diatomite & 11 & {$[47]$} \\
Natural clay mineral & 76 & {$[51]$} \\
Raw ball clay & 34 & {$[52]$} \\
Modified ball clay & 100 & {$[52]$} \\
Natural Moroccan illite-smectite & 100 & This work \\
\hline
\end{tabular}

Table 6 Langmuir, Freundlich and Sips parameters for MB adsorption by the clay sample

\begin{tabular}{llcccc}
\hline & $T\left({ }^{\circ} \mathrm{C}\right)$ & 20 & 25 & 35 & 45 \\
\hline Freundlich model & $K_{\mathrm{F}}\left(\mathrm{mg} \mathrm{g}^{-1}\right)$ & 45.6 & 60.4 & 48.9 & 48.5 \\
& $1 / n$ & 0.186 & 0.100 & 0.168 & 0.181 \\
& $R^{2}$ & 0.863 & 0.862 & 0.826 & 0.849 \\
Langmuir model & $Q_{m}\left(\mathrm{mg} \mathrm{g}^{-1}\right)$ & 91.7 & 93.5 & 95.2 & 100.0 \\
& $K_{\mathrm{L}}\left(\mathrm{L} \mathrm{mg}^{-1}\right)$ & 1.91 & 1.89 & 1.41 & 1.11 \\
& $R^{2}$ & 0.999 & 0.999 & 0.999 & 0.999 \\
Sips model & $Q_{m}\left(\mathrm{mg} \mathrm{g}^{-1}\right)$ & 97.93 & 92.0 & 92.5 & 99.5 \\
& $K_{S}\left(\mathrm{~L} \mathrm{mg}^{-1}\right)$ & 1.04 & 2.87 & 3.60 & 2.11 \\
& $n$ & 0.68 & 0.89 & 1.01 & 0.71 \\
& $R^{2}$ & 0.961 & 0.982 & 0.918 & 0.958 \\
\hline
\end{tabular}

homogeneous sites, which are identical and contain equivalent energy [13].

\subsubsection{Adsorption thermodynamics}

Thermodynamic studies are especially useful for interpreting the adsorption behavior in terms of process equilibrium [48]. Thermodynamic parameters evidencing the influence of temperature can be determined by combining the thermodynamic equation, $\Delta G^{\circ}=\Delta H^{\circ}-T \Delta S^{\circ}$, and van't Hoff equation, which allows achieving the Eyring equation (Eq. 1):

$\operatorname{Ln}\left(k_{\mathrm{e}}^{\circ}\right)=\frac{-\Delta H^{\circ}}{R T}+\frac{\Delta S^{\circ}}{R}$

where $R$ is the universal gas constant $\left(8.314 \mathrm{~J} \mathrm{~K}^{-1} \mathrm{~mol}^{-1}\right)$, $T(\mathrm{~K})$ the absolute temperature, $k_{\mathrm{e}}^{\circ}$ is the thermodynamic equilibrium constant, and $\Delta H^{\circ}$ and $\Delta S^{\circ}$ are the changes in enthalpy and entropy, respectively. Therefore, in this work the thermodynamics of the MB adsorption onto the clay 
was also investigated at different temperatures, in particular at $20,25,35$ and $45^{\circ} \mathrm{C}$. According to the latest estimates of different authors $[53,54]$ to determine thermodynamic parameters, the right way to calculate the equilibrium constant for the adsorption system includes obtaining adsorption isotherms at different temperatures. In this context, it is recommended to use the equation described below (Eq. 2) to determine the thermodynamic parameters:

$K_{\mathrm{e}}^{\circ}=\frac{1000 \cdot K_{\mathrm{L}} \cdot \text { molecular weight of adsorbate } \cdot\left[\text { adsorbate }^{\circ}\right.}{\gamma}$

where $K_{\mathrm{e}}^{\circ} \mathrm{is}$ the thermodynamic equilibrium constant that is dimensionless, $K_{\mathrm{L}}$ is the Langmuir isotherm constant, [adsorbate] ${ }^{\circ}$ is the standard concentration of the adsorbate $\left(1 \mathrm{~mol} \mathrm{~L}^{-1}\right)$, and $\gamma$ is the activity coefficient which is unitary for very diluted or ideal solutions. The average standard enthalpy change of MB adsorption on the clay was estimated using the above equation. The values of $\Delta S^{\circ}$ and $\Delta H^{\circ}$ were obtained from the intercept and slope of the plot of $\ln \left(K_{\mathrm{e}}^{\circ}\right)$ against $1 / T$ (Fig. 10), resulting to be $45.1 \mathrm{~J} \mathrm{~K}^{-1} \mathrm{~mol}^{-1}$ and $-19.5 \mathrm{~kJ} \mathrm{~mol}^{-1}$, respectively, what leads to values of the change in free energy $\left(\Delta G^{\circ}\right)$ around $-33 \mathrm{~kJ} \mathrm{~mol}^{-1}$ in the range of $20-45^{\circ} \mathrm{C}$ (Table 7), with a correlation coefficient for the fitting of 0.994 . Therefore, the process of $\mathrm{MB}$ adsorption on the clay here studied is exothermic $[49,55]$ and spontaneous. Our results contrast with those obtained by other authors $[18,28,43]$ who found positive values for both $\Delta H^{\circ}$ and $\Delta S^{\circ}$ in the case of the adsorption of MB onto a natural montmorillonite, kaolin or diatomite, respectively. On the contrary, our results agree with those reported for the same process over two other clay minerals, one of them mainly composed of quartz, clay, dolomite, hematite and feldspars, and the other consisting of illite associated with very small amounts of chlorite [47]. In any case, it should be noticed that establishing a correlation between thermodynamics of the adsorption process and the mineralogical nature of the clay used as adsorbent is not certainly an easy task. This finding is well illustrated by Omer et al. [56] in a recent paper, in which both, the exo- or endothermic characters, could be observed for a same type of mineral category. This is also reflected on the wide range of values estimated for $\Delta G^{\circ}$ as illustrated in Table 4.

\subsection{Methylene blue adsorption on the clay honeycomb monolith}

After studying the retention of MB on our clay as a powder, we conducted an additional study using it in the form of honeycomb monolith but under dynamic conditions (Fig. 1). Evidences for the MB adsorption on the clay monolith were obtained not only from its coloring after the

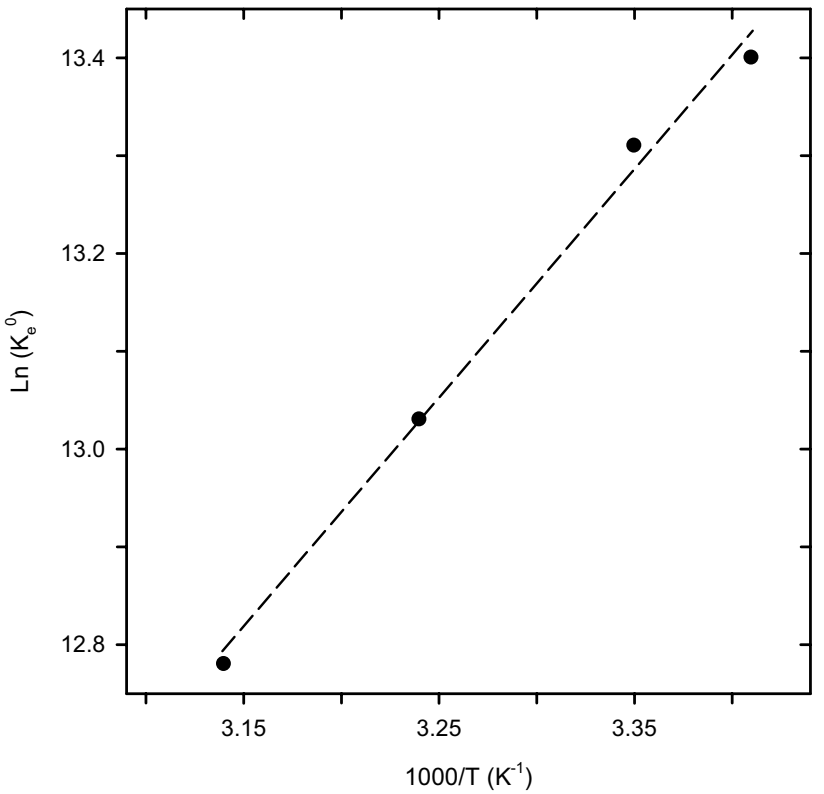

Fig. 10 Thermodynamic study for the MB adsorption on the clay sample, performed through fitting of the experimental data to the linear form of van't Hoff equation

Table 7 Equilibrium constants based on the Langmuir isotherm and after applying Eq. (2) to make it dimensionless and values of Gibbs's free energy calculated from Eq. (1)

\begin{tabular}{llllll}
\hline$T(\mathrm{~K})$ & $K_{\mathrm{L}}\left(\mathrm{L} \mathrm{mg}^{-1}\right)$ & $K_{\mathrm{L}}\left(\mathrm{L} \mathrm{mol}^{-1}\right)$ & $K_{\mathrm{e}}^{\circ}$ & $\mathrm{Ln}\left(K_{\mathrm{e}}^{\circ}\right)$ & $\Delta G^{\circ}\left(\mathrm{kJ} \mathrm{mol}^{-1}\right)$ \\
\hline 293 & 2.06 & $65.78 \times 10^{4}$ & $65.78 \times 10^{4}$ & 13.40 & -32.71 \\
298 & 1.89 & $60.45 \times 10^{4}$ & $60.45 \times 10^{4}$ & 13.31 & -32.94 \\
308 & 1.41 & $45.20 \times 10^{4}$ & $45.20 \times 10^{4}$ & 13.02 & -33.34 \\
318 & 1.11 & $35.54 \times 10^{4}$ & $35.54 \times 10^{4}$ & 12.78 & -33.70 \\
\hline
\end{tabular}

process (Fig. 1) but also through FTIR analysis of crushed pieces (Fig. 2). As it can be observed, new peaks at 1602, $1486,1393,1353$ and $1333 \mathrm{~cm}^{-1}$ were detected after the dye was adsorbed. The first two can be assigned to $C=C$ and $\mathrm{C}=\mathrm{N}$, and $\mathrm{C}=\mathrm{S}^{+}$stretching vibrations of the $\mathrm{MB}$ heterocycle, respectively, while those at lower frequency might be associated with the symmetrical and asymmetrical bending vibrations of the $\mathrm{CH}_{3}$ functional groups of $\mathrm{MB}$ and the stretching vibrations of the $\mathrm{C}-\mathrm{N}$ terminal saturated dimethylamino groups $[56,57]$. It should be added that the position of the peaks previously attributed to the clay was not shifted as a consequence of the interaction with MB. This is consistent with the electrostatic nature of the interaction between adsorbate and adsorbent above suggested by the isotherms. It is also reasonable considering that our clay was not functionalized to enhance its adsorptive performance as other authors did [22]. The only significant change observed after the treatment with $M B$ is 
the recovery of intensity of the bands located in the upper region, reasonably due to rehydration of the calcined clay that constitutes the matrix of the monolith under the aqueous medium treatment.

The recirculated plug-flow tests were performed using two initial concentrations of $\mathrm{MB}, 20$ and $100 \mathrm{mg} \mathrm{L}^{-1}$, in aqueous solution, and also employing a column containing the same quantity of clay in the form of powder and calcined at the same temperature as the monolith for comparative purposes. Figure 11 shows the results obtained in this study. As can be noticed, the adsorptive behavior changes with the initial concentration of the adsorbate. For low concentrations of $\mathrm{MB}\left(C_{0}=20 \mathrm{mg} \mathrm{L}^{-1}\right)$, the differences observed between the two samples studied, honeycomb monolith and packed column, are relatively small. The maximum quantities of pollutant absorbed by the two samples are 2.8 and $2.9 \mathrm{mg} \mathrm{g}^{-1}$, respectively. The obtained curves also show that the elimination of pollutant is almost complete after $3 \mathrm{~h}$ of flow recirculation under the tested experimental conditions. On the contrary, the experiments carried out for higher concentration of $\mathrm{MB}\left(C_{0}=100 \mathrm{mg} \mathrm{L}^{-1}\right)$ allow a clearer differentiation between the two studied samples. The clay-based monolith becomes more efficient adsorbent than the column. Although total elimination of MB cannot be achieved after 500 min of flow, the removal efficiency varies from about $41 \%$ for the clay-based monolith to $37 \%$ for the column that contains the same quantity of powdered clay. These results correspond to an adsorbed amount of 5.9 and $5.1 \mathrm{mg} \mathrm{g}^{-1}$, respectively. Moreover, experiments of much longer duration (not shown) indicated that after $24 \mathrm{~h}$ the monolith and the packed column adsorbed 9.1 and $7.2 \mathrm{mg} / \mathrm{g}$, respectively, confirming the higher removal efficiency of the former ( $58 \%$ vs $48 \%$ in the case of the column). These experiments also demonstrated the reproducibility of the results obtained up to $8 \mathrm{~h}$, with an experimental deviation lower than $2 \%$.

It is also noteworthy that in the case of the packed column the flow measured at the outlet was immediately decreased from 1200 to $400 \mathrm{~cm}^{3} \mathrm{~min}^{-1}$, whereas the flow kept constant during the whole experiment in the case of the monolith. This observation has a double significance. First, it demonstrates the advantage of using the honeycomb monolith to avoid pressure drop problems, a virtue that joins that of easy replacement upon saturation. Second, it gives double value to the results obtained with this design because it operated under less favored conditions for adsorption such as a three times lower contact time than that employed for the packed powder [15]. Moreover, the results obtained with the clay monoliths of this study are also more interesting than those we previously observed for similar clay honeycomb monoliths that even

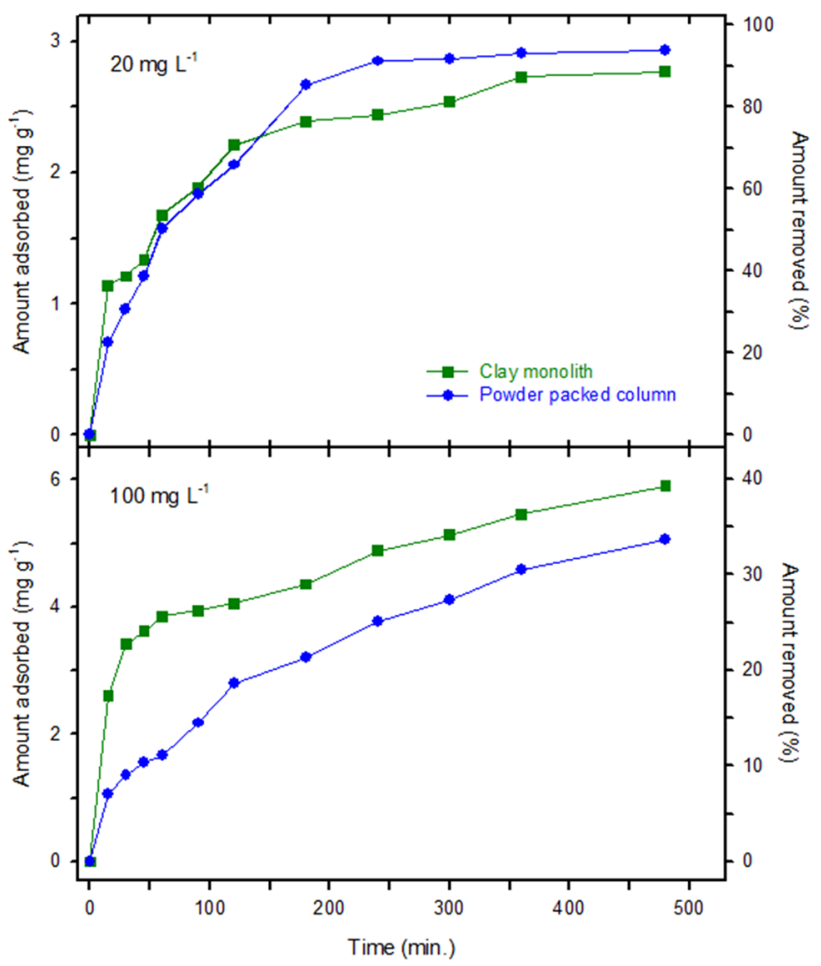

Fig. 11 Methylene blue adsorption at room temperature as a function of time on the clay honeycomb monolith and a packed column containing the same amount of calcined clay

had been activated by means of coal templating, measuring under the same experimental conditions [36].

\section{Conclusion}

According to textural, chemical and structural characterization, the studied raw argillaceous material mainly consisted of a thermally stable interstratified illite-smectite with appropriate porosity and surface area for use as adsorbent. Its maximum methylene blue (MB) adsorption capacity was found to be $100 \mathrm{mg} \mathrm{g}^{-1}$ at $45^{\circ} \mathrm{C}$. The adsorption isotherms of $\mathrm{MB}$ dye could be satisfactorily described by the equations of Langmuir model. The kinetic study of the $\mathrm{MB}$ retention by the clay revealed that the adsorption process is of second order, while the thermodynamic study indicated its exothermic character and spontaneity in the range from 20 to $45^{\circ} \mathrm{C}$.

The results obtained with honeycomb monoliths extruded from this clay without additives were of particular interest. They proved that the application of structured filters under dynamic conditions could be more effective than using packed columns of the same material but in powdered form. For example, the integral clay honeycomb monoliths allowed almost complete removal of MB from 
$1 \mathrm{~L}$ of aqueous solution containing $20 \mathrm{mg} \mathrm{L}^{-1}$ of $\mathrm{MB}$, in recirculating flow experiments and for relatively short times $(<6 \mathrm{~h})$, operating with $6.5 \mathrm{~g}$ weighted monoliths at $1200 \mathrm{~cm}^{3} \mathrm{~min}^{-1}$.

Acknowledgements Financial support from the MINECO-Spain/ FEDER (MAT2017-87579-R and MAT2017-84228-R Projects) and the Junta de Andalucía (FQM-110 group). M. Ahrouch is grateful for its AUE-UCA fellowship. We acknowledge the electron microscopy and X-ray diffraction divisions of the SC-ICyT of University of Cádiz, and Dr. G.A. Cifredo for his help in the XRD analysis.

\section{Compliance with ethical standards}

Conflict of interest The author(s) declare that they have no competing interests.

\section{References}

1. Benguella B, Yacouta-Nour A (1999) Elimination des colorants acides en solution aqueuse par la bentonite et le kaolin. C R Chimie 12:762-771. https://doi.org/10.1016/j.crci.2008.11.008

2. Zollinger H (1987) Color Chemistry-Synthesis, Properties and Application of Organic Dyes and pigments. VCH Publishers, New York. https://doi.org/10.1002/anie.200385122

3. Errais E, Duplay J, Darragi F, M'Rabet I, Aubert A, Huber F, Morvan $G$ (2011) Efficient anionic dye adsorption on natural untreated clay: kinetic study and thermodynamic parameters. Desalination 275:74-81. https://doi.org/10.1016/j.desal.2011.02.031

4. Souabi S, Yaacoubi A, Frouji A, Yacoubi A, Belkhadir EM (1996) Etude de l'elimination des colorants des rejets de l'industrie textile. Tech Sci Méthodes 3:181-185

5. Netpradit S, Thiravetyan P, Towprayoon S (2004) Adsorption of three azo reactive dyes by metal hydroxide sludge: effect of temperature, $\mathrm{pH}$, and electrolytes. J Colloid Interface Sci 270:255-261. https://doi.org/10.1016/j.jcis.2003.08.073

6. Mottaleb M, Littlejohn D (2001) Application of an HPLC e FTIR modified thermospray interface for analysis of dye samples. Anal Sci 17:429-434

7. Arami M, Limaee NY, Mahmoodi NM, Tabrizi NS (2006) Equilibrium and kinetics for the adsorption of direct and acid dyes from aqueous solution by soy meal hull. J Hazard Mater 135:171-179. https://doi.org/10.1016/j.jhazmat.2005.11.044

8. Fernandes AN, Almeida CAP, Menezes CTB, Debacher NA, Sierra MMD (2007) Removal of methylene blue from aqueous solution by peat. J Hazard Mater 144:412-419. https://doi.org/10.1016/j. jhazmat.2006.10.053

9. Bagane M, Guiza S (2000) Elimination d'un colorant des Effluents de l'industrie textile par adsorption. Ann Chim Sci Mat 25:615-626

10. Gupta GS, Prasad G, Singh VN (1990) Removal of chrome dye from aqueous solutions by mixed adsorbents fly ash and coal. Water Res 24:45-50. https://doi.org/10.1016/00431354(90)90063-C

11. Dali-Youcef Z, Bouabdasselem H, Bettahar N (2006) Élimination des composés organiques par des argiles locales. C R Chimie 9(10):1295-1300. https://doi.org/10.1016/j.crci.2006.05.001

12. Akar T, Demir TA, Kiran I, Özcan A, Özcan AS, Tunali S (2006) Biosorption potential of Neurospora crassa cells for decolorization of Acid Red 57 (AR57) dye. J Chem Technol Biotechnol 81:1100-1106. https://doi.org/10.1002/jctb.1462
13. Azharul Islam Md, Sabar S, Benhouria A, Khanday WA, Asif M, Hameed BH (2017) Nanoporous activated carbon prepared from karanj (Pongamia pinnata) fruit hulls for methylene blue adsorption. J Taiwan Inst Chem Eng 74:96-104. https://doi. org/10.1016/j.jtice.2017.01.016

14. Cheng S, Zhang L, Ma A, Xia H, Peng J, Li C, Shu J (2018) Comparison of activated carbon and iron/cerium modified activated carbon to remove methylene blue from wastewater. J Environ Sci 65:92-102. https://doi.org/10.1016/j.jes.2016.12.027

15. Pang J, Fu F, Ding Z, Lu J, Li N, Tang B (2017) Adsorption behaviors of methylene blue from aqueous solution on mesoporous birnessite. J Taiwan Inst Chem Eng 77:168-176. https://doi. org/10.1016/j.jtice.2017.04.041

16. Shakoor S, Nasar A (2016) Removal of methylene blue from artificially contaminated water using citrus limetta peel waste as very low cost adsorbent. J Taiwan Inst Chem Eng 66:154-163. https://doi.org/10.1016/j.jtice.2016.06.009

17. Bentahar Y, Draoui K, Hurel C, Ajouyed O, Khairoun S, Marmier $\mathrm{N}$ (2019) Physico-chemical characterization and valorization of swelling and non-swelling Moroccan clays in basic dye removal from aqueous solutions. J Afr Earth Sci 154:80-88. https://doi. org/10.1016/j.jafrearsci.2019.03.017

18. Rida K, Bouraoui S, Hadnine S (2013) Adsorption of methylene blue from aqueous solution by kaolin and zeolite. Appl Clay Sci 83-84:99-105. https://doi.org/10.1016/j.clay.2013.08.015

19. Chen $P$, Cao Z, Wen X, Wang J, Yang F, Qiu P, Yue Y, Liu G, Wang S, Zhong H (2017) A novel mesoporous silicate material (MS) preparation from dolomite and enhancing methylene blue removal by electronic induction. J Taiwan Inst Chem Eng 80:128-136. https://doi.org/10.1016/j.jtice.2017.08.044

20. El Mouzdahir Y, Elmchaouri A, Mahboub R, Gil A, Korili SA (2007) Adsorption of methylene blue from aqueous solutions on a Moroccan clay. J Chem Eng Data 52:1621-1625. https://doi. org/10.1021/je700008g

21. Shaban M, Abukhadra MR, Khan AAP, Jibali BM (2018) Removal of Congo red, methylene blue and $\mathrm{Cr}(\mathrm{VI})$ ions from water using natural serpentine. J Taiwan Inst Chem Eng 82:102-116. https ://doi.org/10.1016/j.jtice.2017.10.023

22. Zhang Z, Wang W, Wang A (2015) Highly effective removal of methylene blue using functionalized attapulgite via hydrothermal process. J Environ Sci 33:106-115. https://doi.org/10.1016/j. jes.2014.12.014

23. Gatica JM, Vidal H (2010) Non-cordierite clay-based structured materials for environmental applications. J Hazard Mater 181:918. https://doi.org/10.1016/j.jhazmat.2010.05.041

24. Gatica JM, Vidal H (2011) Chapter 7 Use of clays to manufacture honeycomb monoliths for pollution control applications. In: Humphrey JP, Boyd DE (eds) Clay: types; properties and uses. Nova Science Publishers, New York, pp 253-273

25. Ahrouch M, Gatica JM, Draoui K, Bellido D, Vidal H (2019) Lead removal from aqueous solution by means of integral natural clays honeycomb monoliths. J Hazard Mater 365:519-530. https ://doi.org/10.1016/j.jhazmat.2018.11.037

26. Chandrasekhar S, Pramada PN (2006) Rice husk as an adsorbent for methylene blue- effect of ashing temperature. Adsorption 12:27-43. https://doi.org/10.1007/s10450-006-0136-1

27. El Qada EN, Allen SJ, Walker GM (2006) Adsorption of methylene blue onto activated carbon produced from steam activated bituminous coal: a study of equilibrium adsorption isotherm. Chem Eng J 124:103-110. https://doi.org/10.1016/j.cej.2006.08.015

28. Almeida CAP, Debacher NA, Downs AJ, Cottet $L$, Mello CAD (2009) Removal of methylene blue from colored effluents by adsorption on montmorillonite clay. J Colloid Interface Sci 332(1):46-53. https://doi.org/10.1016/j.jcis.2008.12.012

29. Hamdaoui $O$ (2006) Batch study of liquid-phase adsorption of methylene blue using cedar sawdust and crushed brick. J 
Hazard Mater 135:264-273. https://doi.org/10.1016/j.jhazm at.2005.11.062

30. Mohammed MA, Shitu A, Ibrahim A (2014) Removal of methylene blue using low cost adsorbents: a review. Res J Chem Sci 4(1):91-102

31. Rafatullah M, Sulaiman O, Hashim R, Ahmad A (2010) Adsorption of methylene blue on low-cost adsorbents: a review. J Hazard Mater 177:70-80. https://doi.org/10.1016/j.jhazmat.2009.12.047

32. Ciesielski H, Sterckeman T (1997) Determination of cation exchange capacity and exchangeable cations in soils by means of cobalt hexamine trichloride. Effects of experimental conditions. Agronomie 17:1-7. https://doi.org/10.1051/agro:19970 101

33. Hang PT, Brindley GW (1970) Methylene blue adsorption by clay minerals. Determination of surface areas and cation exchange capacities (clay-organic studies XVIII). Clays Clay Minerals 18(4):203-212

34. Cottet $L$, Almeida CAP, Naidek N, Viante MF, Lopes MC, Debacher NA (2014) Adsorption characteristics of Montmorillonite clay modified with iron oxide with respect to methylene blue in aqueous media. Appl Clay Sci 95:25-31. https://doi. org/10.1016/j.clay.2014.03.023

35. Gatica JM, Rodríguez-Izquierdo JM, Sánchez D, Ania C, Parra JB, Vidal H (2004) Extension of preparation methods employed with ceramic materials to carbon honeycomb monoliths. Carbon 42:3252-3254. https://doi.org/10.1016/j.carbon.2004.06.040

36. Cifredo G, Gatica JM, Harti S, Vidal H (2010) Easy route to activate clay honeycomb monoliths for environmental applications. Appl Clay Sci 47:392-399. https://doi.org/10.1016/j.clay.2009.12.003

37. Rodríguez-Carvajal JJ (1993) Recent advances in magnetic structure determination by neutron power diffraction. Phys $B$ 192:55-69. https://doi.org/10.1016/0921-4526(93)90108-I

38. Ho YS (2004) Citation review of Langergren kinetic rate equation on adsorption reactions. Scientometrics 59:171-177

39. Wang L, Wang A (2008) Adsorption properties of Congo red from aqueous solution onto surfactant-modified montmorillonite. J Hazard Mater 160:173-180. https://doi.org/10.1016/j.jhazm at.2008.02.104

40. Chafik T, Harti S, Cifredo G, Gatica JM, Vidal H (2009) Easy extrusion of honeycomb-shaped monoliths using Moroccan natural clays and investigation of their dynamic adsorptive behaviour towards VOCs. J Hazard Mater 170:87-95. https://doi. org/10.1016/j.jhazmat.2009.04.127

41. Harti S, Cifredo G, Gatica JM, Vidal H, Chafik T (2007) Physicochemical characterization and adsorptive properties of some Moroccan clay minerals extruded as lab-scale monoliths. Appl Clay Sci 36:287-296. https://doi.org/10.1016/j.clay.2006.10.004

42. Acemana S, Lahav N, Yariv S (1999) A thermo-FTIR spectroscopy analysis of Al-pillared smectites differing in source of charge, in $\mathrm{KBr}$ disks. Thermochim Acta 340-341:349-366. https://doi. org/10.1016/S0040-6031(99)00281-6

43. Hadri M, Chaouki Z, Zaitan H, Draoui K, Barhoun A, Nawdali M, Valdés H, Drouiche N (2017) Adsorption of a cationic dye from aqueous solution using low-cost Moroccan diatomite: adsorption equilibrium, kinetic and thermodynamic studies. Desalin Water Treat 75:213-224. https://doi.org/10.5004/ dwt.2017.20553

44. Vázquez T, Blanco MT (1981) Tabla de frecuencias y espectros de absorción infrarroja de compuestos relacionados con la química del cemento. Mater Constr 182:31-48. https://doi.org/10.3989/ mc.1981.v31.i182.1007
45. Ríos-León I, Solano-Pola C, Rodríguez-Ruiz J, Espinosa-Fuentes E, Meza-Fuentes E (2017) Study by infrared spectroscopy and thermogravimetry of the effect of temperature on nickel-aluminum hydrotalcites. DYNA 84(201):9-16. https://doi.org/10.15446/ dyna.v84n201.59768

46. Sing KSW, Everett DH, Haul RAW, Moscou L, Pierotti RA, Rouquérol J, Siemieniewska T (1985) Reporting physisorption data for gas/solid systems with special reference to the determination of surface area and porosity. Pure Appl Chem 57(4):603-619. https ://doi.org/10.1351/pac198557040603

47. Elmoubarki R, Mahjoubi FZ, Tounsadi $H$, Moustadraf J, Abdennouri M, Zouhri A, El Albani A, Barka H (2015) Adsorption of textile dyes on raw and decanted Moroccan clays: kinetics, equilibrium and thermodynamics. Water Resour Ind 9:16-29. https ://doi.org/10.1016/j.wri.2014.11.001

48. Namasivayam C, Sureshkumar MV (2006) Anionic dye adsorption characteristics of surfactant modified coir pith, a waste lignocellulosic polymer. J Appl Polym Sci 100:1538-1546. https:// doi.org/10.1002/app.23278

49. Sureshkumar MV, Namasivayam C (2008) Adsorption behavior of Direct Red 12B and Rhodamine B from water onto surfactantmodified coconut coir pith. Colloid Surf A 317:277-283. https:// doi.org/10.1016/j.colsurfa.2007.10.026

50. Doğan M, Özdemir Y, Alkan M (2007) Adsorption kinetics and mechanism of cationic methyl violet and methylene blue dyes onto sepiolite. Dyes Pigm 75(3):701-713. https://doi. org/10.1016/j.dyepig.2006.07.023

51. Giles CH, MacEvan TH, Nakhua SN, Smith D (1960) Studies on adsorption-XI. J Chem Soc 111:3973-3993

52. Giles CH, D'Silva AP, Easton IA (1974) A general treatment and classification of the solute adsorption isotherm. II. Experimental interpretation. J Colloid Interface Sci 47(3):766-778

53. Lima EC, Hosseini-Bandegharaei A, Moreno-Piraján JC, Anastopoulos I (2019) A critical review of the estimation of the thermodynamic parameters on adsorption equilibria. Wrong use of equilibrium constant in the Van't Hoof equation for calculation of thermodynamic parameters of adsorption. J Mol Liq 273:425434. https://doi.org/10.1016/j.molliq.2018.10.048

54. Liu $Y(2009)$ Is the free energy change of adsorption correctly calculated? J Chem Eng Data 54:1981-1985. https://doi. org/10.1021/je800661q

55. Auta M, Hameed BH (2012) Modified mesoporous clay adsorbent for adsorption isotherm and kinetics of methylene blue. Chem Eng J 198-199:219-227. https://doi.org/10.1016/j. cej.2012.05.075

56. Omer OS, Hussein MA, Hussein BHM, Mgaidi A (2018) Adsorption thermodynamics of cationic dyes (methylene blue and crystal violet) to a natural clay mineral from aqueous solution between 293.15 and 323.15 K. Arab J Chem 11(5):615-623. https ://doi.org/10.1016/j.arabjc.2017.10.007

57. Ovchinnikov OV, Evtukhova AV, Kondratenko TS, Smirnov MS, Khokhlov VY, Erina OV (2016) Manifestation of intermolecular interactions in FTIR spectra of methylene blue molecules. Vibr Spectrosc 86:181-189. https://doi.org/10.1016/j.vibsp ec.2016.06.016

Publisher's Note Springer Nature remains neutral with regard to jurisdictional claims in published maps and institutional affiliations. 